\title{
PENGEMBANGAN MODEL PEMBELAJARAN PIPI MAMA DALAM MENINGKATKAN KETERAMPILAN WRITING DI SEKOLAH MENENGAH PERTAMA (SMP)
}

\author{
Iis Farida Zein ${ }^{1}$, Rita Retnowati ${ }^{2}$, Eri Sarimanah ${ }^{2}$ \\ ${ }^{1}$ Guru MTs. Azzainiyyah Nagrog Sinar Barokah, Sukabumi, Jawa Barat \\ ${ }^{2}$ Program Pascasarjana Universitas Pakuan \\ Email: pasca@unpak.ac.id
}

\begin{abstract}
The developed-model of ADDIE used as the research methodology. It aims to create a product of learning model in order to improve student's writing skills. The ADDIE model is a collaboration of Picture and Picture model and Make a Match model. The research started by analyzing the teaching performance and needs at some schools in Komisariat Cisaat; student's writing skills which vocabulary collections needed to be improved, and teacher's passive teaching performance. Designing model-draft of PIPI MAMA is taken after the needs indicated. The developed-model conducted at main field-research in order to see whether the developed-model could improve the writing skills at school. The conclusion is that ADDIE developed-model is an affective learning model.
\end{abstract}

Key words: ADDIE, picture and picture, make a match, picture series, vocabularies

\begin{abstract}
ABSTRAK
Guru dituntut mampu mengembangkan model pembelajaran. Metodologi penelitian ini menggunakan model ADDIE yang bertujuan untuk menciptakan suatu produk dalam bentuk model pembelajaran untuk meningkatkan keterampilan menulis siswa. Model pembelajaran ini merupakan kolaborasi dari model pembelajaran sebelumnya, yaitu: model pembelajaran picture and picture yang merupakan model pembelajaran yang mengandalkan gambar, dan model pembelajaran Make a match untuk memperkaya dan memperkuat kosakata. Penelitian ini dimulai dengan menganalisis kinerja pengajaran dan kebutuhan di sekolah-sekolah di Komisariat Cisaat dan masalah yang ditemukan adalah keterampilan menulis siswa semakin menurun. Itu disebabkan oleh kurangnya kosakata. Masalah ini juga semakin memburuk oleh model pembelajaran konvensional yang telah digunakan oleh para guru. Merancang draf model pembelajaran PIPI MAMA adalah langkah selanjutnya yang harus dilakukan berdasarkan hasil analisis langkah. Langkah selanjutnya id Mengembangkan model pembelajaran PIPI MAMA dengan menggunakan teknik Delphi, uji pendahuluan dan dephi2. tes pendahuluan membawa saran dan masukan untuk model pembelajaran dari penilaian ahli yang berbahagia di Delphi 2 untuk melengkapi kelemahan model pembelajaran. teknik pengumpulan data adalah dengan observasi, kuesioner, dan tes keefektifan model pembelajaran ini. Hasilnya adalah: data enthutiasme siswa terhadap penerapan model pembelajaran, respon siswa terhadap model pembelajaran, kesesuaian model oleh ahli, guru model, dan nilai pretest. dan posttest siswa. Hasil Delphi 2 adalah rancangan model pembelajaran PIPI MAMA yang akan diuji dalam uji lapangan utama. Langkah selanjutnya adalah menerapkan model dalam pengujian lapangan utama untuk mengetahui apakah model pembelajaran ini dapat memecahkan masalah keterampilan menulis di sekolah
\end{abstract}


Katakunci: ADDIE, picture and picture, make a match, picture series, vocabularies

\section{PENDAHULUAN}

Pendidikan adalah salah satu wujud kebudayaan manusia yang dinamis dan selalu berkembang. Perubahan atau perkembangan pendidikan adalah hal mutlak yang pasti terjadi seiring dengan perkembangan kebudayaan manusia. Perubahan kepada hal yang lebih baik dilakukan untuk mengantisipasi apa yang akan dihadapi oleh generasi yang akan datang.

Undang-undang nomor 20 tahun 2003 tentang sistem pendidikan nasional menyebutkan, bahwa pendidikan nasional berfungsi mengembangkan kemampuan dan membentuk watak serta peradaban bangsa yang bermartabat dalam rangka mencerdaskan kehidupan bangsa. Pendidikan bertujuan untuk mengembangkan potensi siswa agar menjadi manusia yang beriman dan bertaqwa kepada Tuhan yang Maha Esa, berakhlak mulia, sehat, berilmu, cakap, kreatif, mandiri, dan menjadi warga negara yang demokratis serta bertanggungjawab.

Tantangan untuk tetap mempertahankan budaya dan karakter bangsa dewasa ini sangatlah kompleks dan multidimensi, ditambah lagi dengan persaingan global yang sudah tak bisa dihindari lagi. Pendidikan Indonesia perlu dikembangkan dan dikuatkan agar siap menghadapi globalisasi dengan sumberdaya manusia yang juga harus siap bersaing dengan seluruh negara di dunia. Peningkatan mutu pendidikan menjadi agenda utama yang digulirkan dalam perkembangan pendidikan oleh pemerintah di Indonesia, program-program peningkatan mutu pun secara bertahap diberlakukan kepada seluruh pihak yang terkait.

\section{Model Pembelajaran Bahasa Inggris}

\section{a. Model Pembelajaran}

Mills berpendapat (dalam Suprijono, 2016: 64) bahwa model adalah bentuk refresentasi akurat sebagai proses aktual yang memungkinkan seseorang atau sekelompok orang mencoba bertindak berdasarkan model itu, model merupakan interpretasi terhadap hasil observasi dan pengukuran yang diperoleh dari beberapa system. Trianto $(2009$;17) Pembelajaran adalah usaha sadar dari seorang guru untuk membelajarkan siswanya dalam rangka mencapai tujuan yang diharapkan.Pembelajaran juga dapat diartikan sebagai produk interaksi berkelanjutan antara pengembangan dan pengalaman hidup.

Dengan demikian dapat disimpulkan bahwa model pembelajaran adalah rangkaian dari pendekatan, strategi, metode dan teknik pembelajaran. Dengan kata lain model pembelajaran merupakan bentuk pembelajaran yang tergambar dari awal sampai akhir yang disajikan secara khas oleh guru dalam menyampaikan pesan atau materi pelajaran.

\section{b. Bahasa Inggris}

Fungsi bahasa tentu sangat banyak, bahasa adalah alat berfikir. Ketika sebuah gagasan atau ide timbul dalam pikiran, ide itu bukanlah bahasa karena belum mempunyai bentuk tertentu. Tetapi ketika gagasan itu sudah dituangkan dan diatur urutan unsur-unsurnya dalam bentuk kata atau kalimat yang diucapkan dengan lisan atau dicatat dengan simbol-simbol berupa tulisan, gagasan itu berubah menjadi bahasa karena sudah mempunyai bentuk yang berwujud (Izzam, 2008:4)

Berdasarkan uraian di atas dapat disimpulkan bahwa Bahasa Inggris merupakan alat untuk berkomunikasi baik secara lisan maupun tulisan, memahami dan mengemukakan informasi, pikiran perasaan, dan mengembangkan ilmu pengetahuan, teknologi dan budaya. Pada akhirnya akan memahami dan menghasilkan teks lisan dan tulisan yang terealisasi dalam empat keterampilan; mendengarkan, berbicara, membaca dan menulis. 


\section{Picture and Picture}

Picture and Picture adalah salah satu bentuk model pembelajaran yang termasuk pada kelompok model pembelajaran kooperatif (Cooperrative Learning). Picture and Picture juga merupakan strategi pembelajaran yang kegiatan pembelajarannya dikerjakan oleh guru dan siswa sehingga tujuan pembelajarannya dapat dicapai secara efektif dan efisien (Sanjaya, 2008: 126). Sutirman (2013:14) Picture and Picture adalah suatu model pembelajaran yang pada prosesnya mengandalkan gambar.

Berdasarkan paparan di atas dapat disimpulkan bahwa media pembelajaran adalah alat dan bahan yang dapat digunakan untuk tujuan pendidikan dan pembelajaran, meliputi perangkat keras (Hardware) maupun perangkat lunak (software).

\section{Make a Match}

Model pembelajaran kooperatif tipe mencari pasangan pertama kali dikenalkan oleh Curran. Model make a match atau mencari pasangan merupakan salah satu alternatif yang dapat diterapkan kepada siswa. Penerapan metode ini dimulai dengan teknik siswa diminta untuk mencari pasangan kartu yang merupakan jawaban atau soal sebelum batas waktunya, siswa yang dapat mencocokkan kartunya diberi poin (Hidayat, 2016: 103).

Berdasarkan teori-teori di atas maka dapat disintesiskan bahwa model make a match atau mencari pasangan adalah metode yang memerlukan persiapan, hal-hal yang harus dipersiapkan adalah kartu yang berisi pertanyaan dan jawaban. Peran guru tetap penting dalam metode ini sebagai pembimbing dan fasilitator.

\section{Model Pembelajaran PIPI MAMA}

Model pembelajaran PIPI MAMA adalah model pembelajaran hasil kolaborasi dari beberapa model, teknik dan media pembelajaran yang dianggap mampu dan dapat digunakan untuk mengatasi permasalahan dalam pembelajaran terutama pembelajaran bahasa Inggris dalam masalah kurangnya kosakata siswa untuk meningkatkan kemampuan dan keterampilan menulisnya. Model ini menggunakan metode student centre yang mana siswa menjadi subjek belajar dan guru hanya menjadi fasilitator.

Berdasarkan data di atas dapat disintesiskan bahwa model pembelajaran PIPI MAMA adalah model pembelajaran yang menuntut siswa untuk belajar secara berkelompok, bekerjasama dengan siapapun tanpa pilih-pilih, berfikir cepat, tepat dan aktif sehingga tanpa disadari siswa dapat mencari informasi dan memecahkan masalah bersama-sama, siswa pun dapat mengingat kosakata dengan jumlah yang banyak dalam waktu yang singkat.

\section{Keterampilan Menulis ( writing skill )}

Menurut Nida, Haris dan Tarigan keterampilan berbahasa mempunyai empat komponen, yaitu: 1) keterampilan menyimak; 2) keterampilan berbicara; 3) keterampilan membaca; 4) keterampilan menulis (Tarigan, 2008,:1). Menulis merupakan suatu kegiatan penyampaian informasi atau pesan dengan menggunakan bahasa tulis sebagai alat atau media. Pesan atau informasi ini yaitu berupa isi atau muatan yang terkandung dalam sebuah tulisan, dan tulisan tersebut merupakan sebuah symbol atau lambang yang dapat dilihat dan disepakati penggunanya. (Slamet, 2008: 72).

Berdasarkan teori-teori di atas maka dapat disintesiskan bahwa kegiatan menulis membuat seseorang lebih banyak menyerap, mencari, serta menguasai informasi yang berhubungan dengan topik yang akan ditulis. Dengan demikian, kegiatan menulis dapat memperluas wawasan, baik secara teoritis maupun mengenai fakta-fakta yang berhubungan. 


\section{Pengembangan Model}

Salah satu model desain system pembelajaran yag memperlihatkan tahapan-tahapan dasar desain system pembelajaran yang sederhana dan mudah dipelajari adalah model ADDIE. Model ini sesuai dengan namanya, terdiri dari lima tahap utama, yaitu: $(A)$ nalysis, $(D) e s i g n$, (D)evelopment, (I)mplementation, dan (E)valuation.

Berdasarkan paparan teori-teori di atas dapat ditarik kesimpulan bahwa Penelitian dan Pengembangan (Research\& Development) dan ADDIE adalah metode penelitian yang secara sengaja, sistematis, bertujuan dan diarahkan untuk mencaritemukan, merumuskan, memperbaiki, mengembangkan, menghasilkan, menguji keefektifan produk, model, metode/strategi/cara, jasa, prosedur tertentu yang lebih unggul, baru, baru, efektif, efisien, produktif dan bermakna.

\section{METODE PENELITIAN}

Metode penelitian yang digunakan adalah metode Penelitian dan Pengembangan (Research and Development/ $R \& D$ ) dengan model ADDIE (Analysis, Design, Development, Implementation, Evaluation).

Penelitian ini dilakukan di 1 SMP Negeri dan 2 SMP swasta yang ada dikomisariat Cisaat, kabupaten Sukabumi, provinsi Jawa Barat. Waktu pelaksanaan selama satu semester genap tahun pelajaran 2017-2018. Pada pelaksanaan uji coba model pembelajaran akan dilaksanakan oleh tiga orang guru model dari anggota MGMP Bahasa Inggris yang sekolahnya diminta untuk menjadi tempat pelaksanaan uji coba model secara terbatas dan uji coba secara luas.

\section{HASIL PENELITIAN Writing Skill}

Dari hasil evaluasi yang diperoleh oleh siswa pada uji coba terbatas yang dilaksanakan di SMP Azzainiyyah setelah proses penerapan model pembelajaran PIPI MAMA menunjukan adanya peningkatan dari hasil pra uji coba model yaitu dengan nilai terendah 60 dan nilai tertinggi 72, meningkat setelah tindakan yaitu nilai terendah 80 dan nilai tertinggi 92.

Berdasarkan data menunjukan peningkatan yang cukup baik. Hasil pra uji coba terbatas nilai terendah 60 dan uji coba terbatas nilai tertinggi 72. Perolehan nilai menulis bahasa Inggris belum semua siswa mencapai KKM yang ditetapkan yaitu 75, karena masih ada siswa yang memdapatkan nilai dibawah 70 . Hasil nilai uji coba terbatas pada siswa yang mendapatkan tindakan mengalami peningkatan terbukti perolehan nilai terendah menjadi 80 dan nilai tertinggi 92.

Dari hasil evaluasi yang diperoleh oleh siswa pada uji coba luas yang dilaksanakan di SMPN 1 Cisaat setelah proses penerapan model pembelajaran PIPI MAMA menunjukan adanya peningkatan dari hasil pra uji coba model yaitu dengan nilai terendah 63 dan nilai tertinggi 76, meningkat setelah dikenakan tindakan yaitu nilai terendah 66 dan nilai tertinggi 86, dan di SMP Nurul Ikhwan dengan nilai terendah 70 dan nilai tertinggi 86 untu pra uji coba dan nilai terendah 73 dan tertinggi 93 setelah dikenakan tindakan. 
Tabel 22. Nilai Uji Coba Luas

\begin{tabular}{|c|c|c|c|c|c|}
\hline \multirow{2}{*}{ No } & \multirow{2}{*}{ Kriteria } & \multicolumn{2}{|c|}{$\begin{array}{c}\text { Ketercapaian SMPN } 1 \\
\text { Cisaat }\end{array}$} & \multicolumn{2}{|c|}{$\begin{array}{l}\text { Ketercapaian SMP } \\
\text { Nurul Ikhwan }\end{array}$} \\
\hline & & $\begin{array}{l}\text { Pra Uji } \\
\text { Coba }\end{array}$ & Uji Coba & $\begin{array}{c}\text { Pra Uji } \\
\text { Coba }\end{array}$ & Uji Coba \\
\hline 1 & Nilai Terendah & 72 & 76 & 68 & 88 \\
\hline 2 & Nilai Tertinggi & 84 & 100 & 72 & 100 \\
\hline 3 & Nilai Rata-rata & 73,53 & 94,46 & 68,44 & 94,07 \\
\hline
\end{tabular}

Berdasarkan tabel nilai hasil uji coba luas untuk diatas maka diperoleh hasil rekapitulasi yang dapat divisualkan pada diagram berikut;

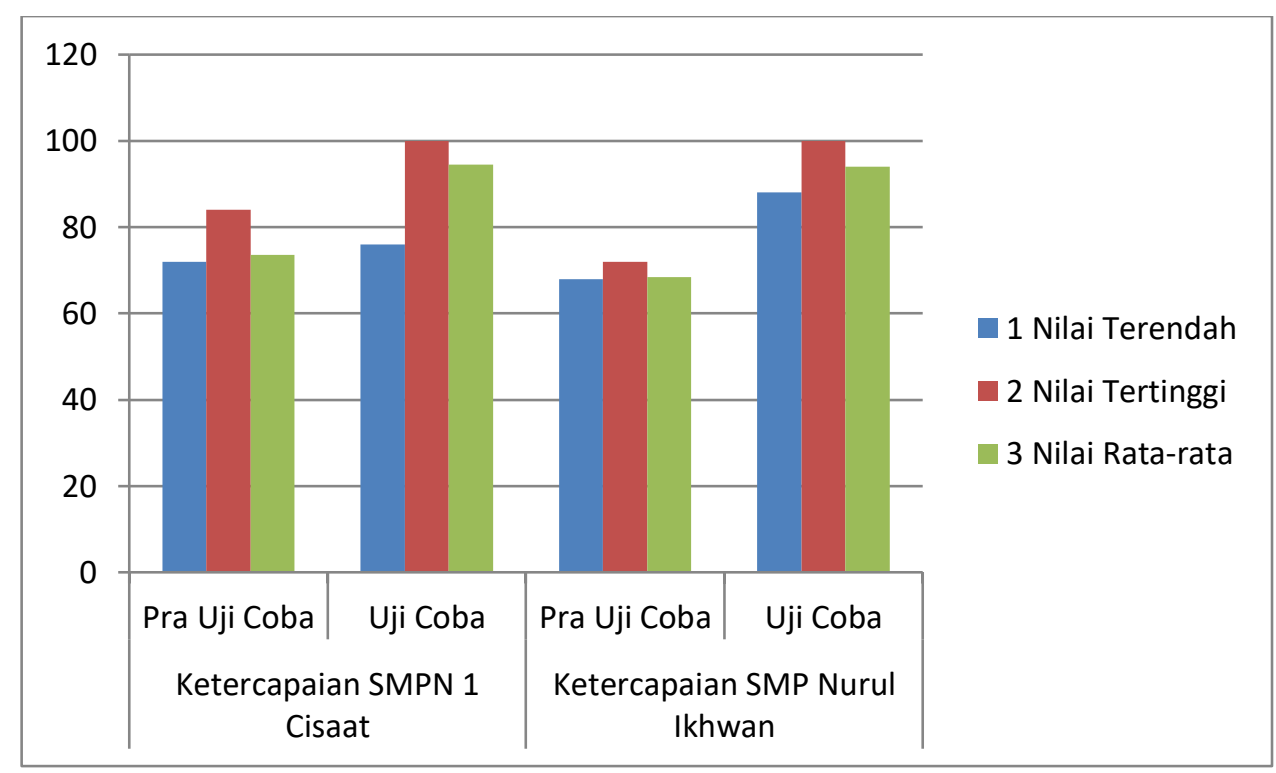

\section{Gambar 16. Diagram nilai uji coba luas}

Menurut Grafik diatas, pada uji coba luas menunjukan peningkatan yang cukup baik. Hasil pra uji coba luas di SMPN 1 Cisaat nilai terendah 68 dan nilai tertinggi 84, sedangkan hasil pra uji coba luas di SMP Nurul Ikhwan nilai terendah 68 dan nilai tertinggi 72 . Perolehan nilai Writing Skill bahasa Inggris belum semua siswa mencapai KKM yang ditetapkan yaitu 75 , karena masih ada siswa yang memdapatkan nilai dibawah 75 . Hasil nilai uji coba luas di SMPN 1 Cisaat nilai siswa yang mendapatkan tindakan mengalami peningkatan terbukti perolehan nilai terendah menjadi 76 dan nilai tertinggi 100 dan nilai terendah pada uji coba luas di SMP Nurul Ikhwan 88 dan niali tertingginya adalah 100.

Berdasarkan grafik pada gambar 6 dan 7 dapat disimpulkan bahwa pelaksanaan pembelajaran dengan menggunakan model pembelajaran PIPI MAMA mampu meningkatkan keterampilan menulis siswa.

\section{Antusiasme Siswa}

Hasil Antusiasme Siswa adalah salah satu yang menjadi poin pengamatan dalam pelaksanakan penelitian dan pengembangan (Research and Development). Pengamatan antusiasme siswa diamati pada setiap tindakan dalam setiap uji coba berlangsung. 
Berdasarkan data hasil antusiasme siswa pada pada saat pertemuan pertama pada uji coba terbatas di SMP Azzainiyyah rata-rata aktivitas on tasknya adalah $98.8 \%$ dan Off tasknya adalah $1.3 \%$ dan keadaannya stabil di tindakan kedua $98.8 \%$ dan off tasknya adalah $1.2 \%$.

Tabel 24. Presentase Antusiasme Siswa pada uji coba Luas

\begin{tabular}{|c|c|c|c|c|}
\hline \multirow{2}{*}{$\begin{array}{c}\text { Aktivitas yang } \\
\text { diamati }\end{array}$} & \multicolumn{2}{|c|}{ SMPN 1 Cisaat } & \multicolumn{2}{c|}{ SMP Nurul Ikhwan } \\
\cline { 2 - 5 } & $\begin{array}{c}\text { Tindakan } \\
1\end{array}$ & $\begin{array}{c}\text { Tindakan } \\
2\end{array}$ & $\begin{array}{c}\text { Tindakan } \\
1\end{array}$ & $\begin{array}{c}\text { Tindakan } \\
2\end{array}$ \\
\hline $\begin{array}{c}\text { Antusiasme } \\
\text { Siswa }\end{array}$ & & & & \\
\hline Off task & 12.5 & 10.33 & 8.19 & 5.83 \\
\hline (On Task) & 87.5 & 89.77 & 91.81 & 94.83 \\
\hline
\end{tabular}

Rekapitulasi hasil observasi antusiasme pada uji coba luas di SMPN 1 Cisaat dan di SMP Nurul Ikhwan dapat divisualkan pada diagram berikut;

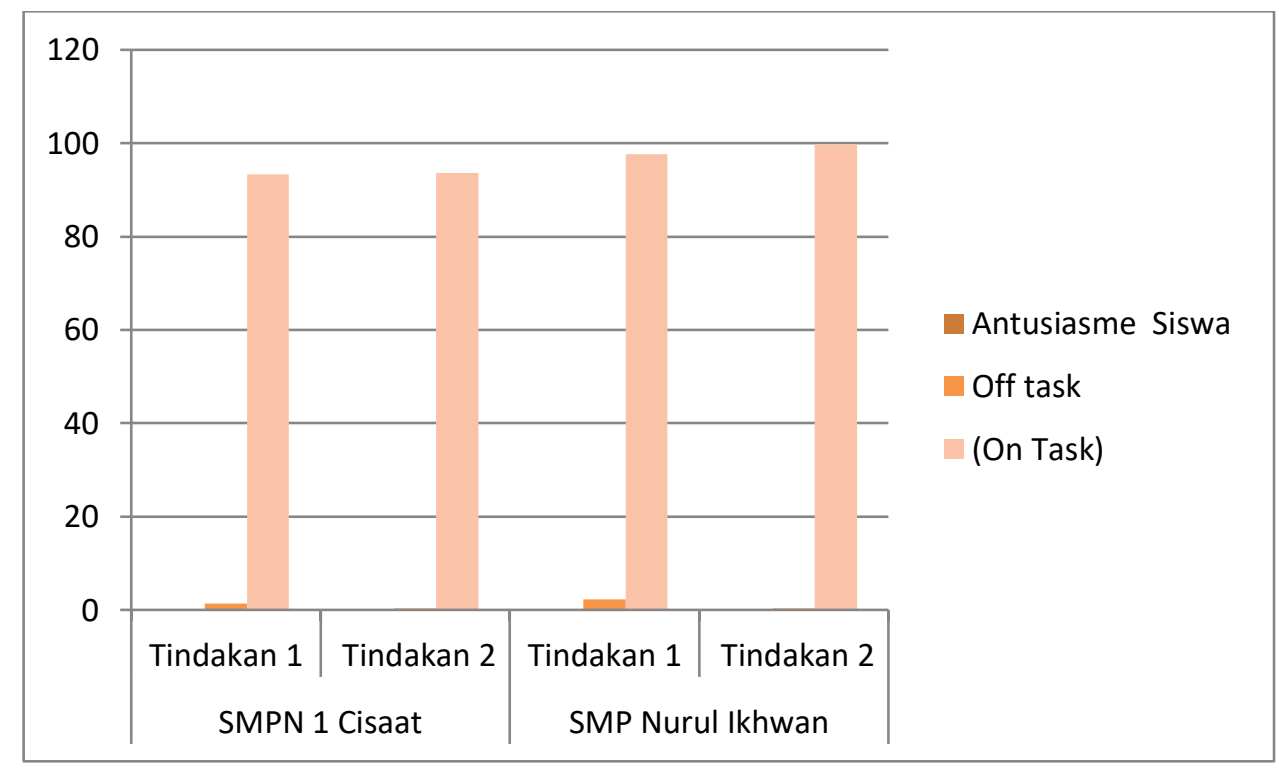

Gambar 18. Diagram antusiasme siswa pada uji coba luas

Dari tabel 24 dan gambar 12 diperoleh hasil antusiasme siswa pada pada saat pertemuan pertama pada uji coba luas di SMPN 1 Cisaat rata-rata aktivitas on tasknya adalah 93,4 \% dan Off tasknya adalah $1,3 \%$ terjadi perubahan kearah yang lebih baik, pada pertemuan kedua On tasknya adalah $93,6 \%$ dan off tasknya adalah $0,3 \%$.

Dari tabel 24 dan gambar 12 juga diperoleh Hasil antusiasme siswa pada pada saat pertemuan pertama pada uji coba luas di SMP Nurul Ikhwan rata-rata aktivitas on tasknya adalah 93,6\% dan Off tasknya adalah 2,3\% terjadi perubahan kearah yang lebih baik, pada pertemuan kedua On tasknya adalah $99,7 \%$ dan off tasknya adalah $0,3 \%$.

Berdasarkan gambar 11 dan 12 dapat disimpulkan bahwa pembelajaran dengan menggunakan model pembelajaran PIPI MAMA dapat meningkatkan antusiasme siswa dalam belajar karena dalam proses pembelajarannya tercipta lingkungan pembelajaran yang 
mempengaruhi kegiatan pembelajaran individu yakni adanya kerjasama kelompok dimana semua anggotanya diharapkan kontribusinya dalam proses pembelajaran.

\section{Hasil Kuisioner Siswa}

Hasil penyebaran kuisioner kepada siswa di tiga sekolah yang menjadi sasaran penelitian setelah pembelajaran berlangsung, dapat diambil kesimpulan bahwa :

TABEL 25. REKAPITULASI KUESIONER

\begin{tabular}{|c|c|c|}
\hline NO & NAMA SEKOLAH & PROSENTASE \% \\
\hline 1 & SMPAZZAINIYYAH & 96 \\
\hline 2 & SMPN 1 CISAAT & 99 \\
\hline 3 & SMP NURUL IKHWAN & 97 \\
\hline
\end{tabular}

1. Kepuasan siswa pada uji coba terbatas di SMP Azzainiyyah terhadap keberhasilan proses pembelajaran dengan menggunakan model pembelajaran PIPI MAMA adalah positif berdasarkan prosentase yang diperoleh yakni $96 \%$.

2. Kepuasan siswa pada uji coba luas di SMPN 1 Cisaat terhadap keberhasilan proses pembelajaran dengan menggunakan model pembelajaran PIPI MAMA adalah positif berdasarkan prosentase yang diperoleh yakni $99 \%$.

Kepuasan siswa pada uji coba luas di SMP Nurul Ikhwan terhadap keberhasilan proses pembelajaran dengan menggunakan model pembelajaran PIPI MAMA adalah positif berdasarkan prosentase yang diperoleh yakni $97 \%$.

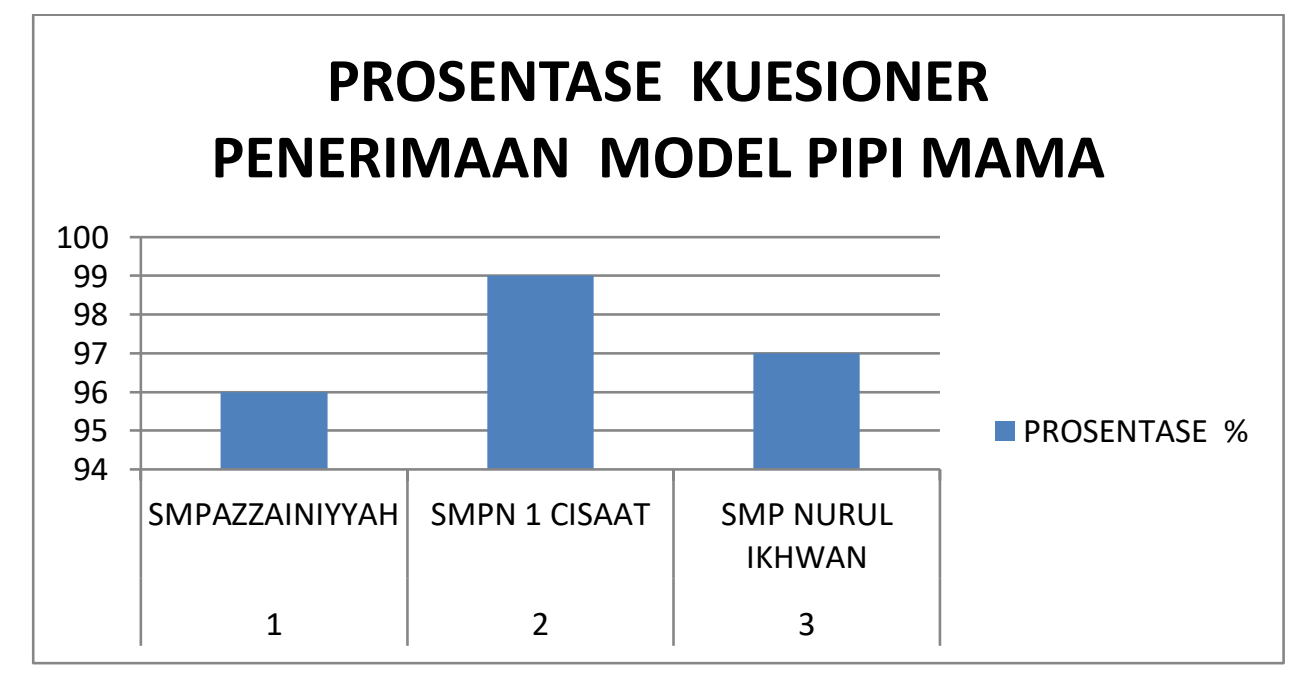

\section{Gambar 19. Grafik kuesioner}

Dari grafik diatas dapat disimpulkan bahwa siswa mmemberikan respon yang baik terhadap kuesioner yang berkaitan dengan pelaksanaan pembelajaran yang menggunakan 
model pembelajaran PIPI MAMA hal ini bisa disimak pada tabel 28 dan grafik pada gambar 12. Dengan demikian hal ini sejalan dengan pendapat Suharsimi yang mengemukakan bahwa Angket/ kuesioner adalah daftar pertanyaan yang disebarkan kepada orang lain yang bersedia memberikan respon sesuai permintaan pengguna.

\section{PEMBAHASAN}

Berdasarkan hasil uji coba terbatas dan uji coba luas serta uji keefektifan model oleh Expert Judgement maka terciptalah model pembelajaran terekomendasi PIPI MAMA hasil dari kolaborasi model Picture and picture dan Make a match yang sudah di modifikasi. Model pembelajaran PIPI MAMA menekankan pada pengembangan cara berfikir dan daya imaginasi siswa, kesigapan dan ketepatan, dan keaktifan saat proses belajar dan melatih siswa untuk bekerjasama dengan orang lain. Cirri model PIPI MAMA adalah: pertama, teliti pada proses mengamati gambar yang secara tidak langsung melatih siswa untuk mendayagunakan indra penglihatan untuk mendapatkan informasi. Kedua, memperkaya perbendaharaan kata karena siswa secara langsung mencari kata yang tersirat pada gambar dan mencari arti kata tadi dalam Bahasa Inggris. Ketiga, inovatif dan mandiri dalam arti siswa menemukan kosakatanya sendiri dan menterjemahkannya sendiri. Keempat, berfikir cepat dan aktif karena siswa dituntut untuk bergerak cepat, aktif, dan tepat dalam neyusun gambar dan kalimatnya.

Salah satu keunggulan model pembelajaran PIPI MAMA adalah siswa secara aktif menjadi subjek pembelajar mandiri yang dimulai dengan siswa mengamati gambar untuk mendapatkan kata yang tersirat, berdiskusi dengan kelompoknya untuk mengetahui artinya dalam bahasa Inggris, berdiskusi dengan kelompoknya untuk menyusun kata menjadi kalimat yang mendeskripsikan gambar dan berfikir kritis dengan menilai hasil dari kelompok lain dengan ini siswa bisa lebih memahami materi pokok pembelajaran.

Berdasarkan data keterampilan menulis siswa tersebut selaras dengan teori Henry Tarigan (2008:3) menulis adalah keterampilan berbahasa yang menuntut pelakunya untuk terampil menggunakan kosa kata dan struktur bahasa.

Pembelajaran yang dilakukan baik pada saat uji coba terbatas maupun uji coba luas tidak hanya dapat meningkatkan keterampilan menulis siswa tapi juga meningkatkan antusiasme siswa dalam mempelajari Bahasa Inggris.

Berdasarkan data diatas maka dapat disimpulkan bahwa antusiasme siswa pada saat pembelajaran dengan menggunakan model PIPI MAMA dalam semua uji coba dapat dikategorikan sangat tinggi. Siswa terlibat secara aktif dengan suasana kelas yang menyenangkan sehingga siswa menjadi percaya diri dalam mengungkapkan ide dan kreatif dalam menyusun strategi bekerjasama dalm menyelesaikan masalah

\section{SIMPULAN}

Berdasarkan proses pengembangan model yang sudah dilaksanakan dan validasi model oleh Expert Judgement melalui penelitian dan pengembangan (Research and Development) maka diperoleh hasil yaitu sebuah model terekomendasi dengan nama Model Pembelajaran PIPI MAMA (Picture and picture dan Make a match).

Model pembelajaran PIPI MAMA adalah model pembelajaran yang dirancang untuk menjawab permasalahan pembelajaran dan kesenjangan kemampuan yang banyak ditemukan dalam proses pembelajaran. Model ini lahir dari sebuah kolaborasi dari dua model pembelajaran yang sudah ada (Picture and picture dan Make a match) yang diharapkan dapat membuat proses pembelajaran lebih menarik, meningkatkan antusias dalam belajar dan efektif dalam menyampaikan materi ajar. 
Berdasarkan rata-rata nilai Writing Skill yang meningkat dari sebelum uji coba, maka dapat disimpulkan bahwa pembelajaran Bahasa Inggris dengan menggunakan model pembelajaran PIPI MAMA dapat meningkatkan antusiasme belajar siswa dalam belajar dan secara signifikan meningkatkan nilai, hal ini menunjukan bahwa penelitian dan pengembangan yang telah dilaksanakan dikatakan berhasil.

\section{DAFTAR PUSTAKA}

Agus Suprijono. 2015. Coorperative Learning Teori dan Aplikasi PAIKEM . Yogyakarta : PUSTAKA PELAJAR.

Agus D Priyanto. 2010. Standar kompetensi. agusdepe.staff.uns.ac.id/files/2010 /09/36-bhsInggris-smp-mts.rtf.. diakses tanggal 21 september 2017.

Ahmad Izzam. 2008. Metodologi Pembelajaran Bahasa Inggris. Bandung : Humaniora.

Benny A. Pribadi. 2009. Model Desain Sistem Pembelajaran. Jakarta : Dian Rakyat.

Borg,W,R.et.al. 2002. Educational Research:An Introduction. Newyork \& London : Longman Inc.

Depdiknas. 2002. Model-Model Pembelajaran. Jakarta : Diknas Dikmen.

Endang Komara. 2014. Belajar dan Pembelajaran interaktif. Bandung : Refika Aditama.

Harjasuna dan Damayanti. 2003. Membaca dalam Teori dan Praktek., Bandung : Mutiara.

http://modelpembelajarankooperatif.blogspot.co.id/2012/08/numbered-head-together$\underline{\text { nht.html }}$

Henry Guntur Tarigan. 2008. MENULIS sebagai suatu keterampilan berbahasa. Bandung : Angkasa.

Iwan Sugiarto. 2004. Mengoptimalkan Daya Kerja Otak dengan Berfikir Holistik dan Kreatif. Jakarta : Gramedia Utama.

Kementrian Pendidikan dan Kebudayaan. 2017. Materi bimbingan teknis fasilitator dan instruktur kurikulum 2013. Jakarta.

Kementrian Pendidikan dan Kebudayaan. 2013. Modul PLPG. Jakarta.

M. Atar Semi. 2007. Dasar-Dasar Keterampilan Menulis. Bandung : Angkasa.

Nurgiantoro. 2009. Penilaian dalam Pengajaran Bahasa dan Sastra. Yogyakarta : BPFE

Nurhadi. 2017. Handbook of Writing -Panduan Lengkap Menulis. Jakarta : PT. Bumi Aksara.

Sugiyono. 2006. Metode Penelitian Pendidikan. Bandung : Alfabeta.

St. Y. Slamet. 2008. Dasar-dasar Pembelajaran Bahasa dan Sastra Indonesia di Sekolah Dasar. Surakarta : UNS Press.

Sutirman. 2013. Media \& Model-model Pembelajaran Inovatif. Yogyakarta : Graha Ilmu.

Tarigan. 2009. Strategi Pengajaran dan Pembelajaran Bahasa. Bandung,: Angkasa

Tri Wiratno. 2003. Kiat Menulis Karya Ilmiah Dalam Bahasa Inggris. Yogyakarta : Pustaka Pelajar.

Trianto. 2009. Mendesain Model Pembelajaran yang inovatif -progressif. Jakarta : Kencana Prenada Media Group.

Ujang S. Hidayat. 2016. Model-Model Pembelajaran Efektif. Sukabumi : Yayasan Budhi Mulia Sukabumi.

Wina Sanjaya. 2008. Perencanaan \& Desain Sistem Pembelajaran. Jakarta : Kencana Prenada Media. 